\title{
Forkhead transcription factors: new considerations for alzheimer's disease and dementia
}

\author{
Kenneth Maiese* \\ Cellular and Molecular Signaling, Newark, New Jersey 07101
}

\begin{abstract}
Life expectancy of individuals in both developed and undeveloped nations continues to rise at an unprecedented rate. Coupled to this increase in longevity for individuals is the rise in the incidence of chronic neurodegenerative disorders that includes Alzheimer's disease (AD). Currently, almost ten percent of the population over the age of 65 suffers from $\mathrm{AD}$, a disorder that is presently without definitive therapy to prevent the onset or progression of cognitive loss. Yet, it is estimated that $\mathrm{AD}$ will continue to significantly increase throughout the world to impact millions of individuals and foster the escalation of healthcare costs. One potential target for the development of novel strategies against $\mathrm{AD}$ and other cognitive disorders involves the mammalian forkhead transcription factors of the $\mathrm{O}$ class (FoxOs). FoxOs are present in "cognitive centers" of the brain to include the hippocampus, the amygdala, and the nucleus accumbens and may be required for memory formation and consolidation. FoxOs play a critical role in determining survival of multiple cell types in the nervous system, drive pathways of apoptosis and autophagy, and control stem cell proliferation and differentiation. FoxOs also interface with multiple cellular pathways that include growth factors, Wnt signaling, Wnt1 inducible signaling pathway protein 1 (WISP1), and silent mating type information regulation 2 homolog 1 (Saccharomyces cerevisiae) (SIRT1) that ultimately may control FoxOs and determine the fate and function of cells in the nervous system that control memory and cognition. Future work that can further elucidate the complex relationship FoxOs hold over cell fate and cognitive function could yield exciting prospects for the treatment of a number of neurodegenerative disorders including AD.
\end{abstract}

\section{Assessing the role of FoxO transcription factors for Alzheimer's disease and cognitive loss}

Increased life expectancy of the global population with increased prevalence of cognitive disorders

Life expectancy throughout the globe continues to rise in both developed nations as well as in large nations that are under development [1]. For example, in China, the number of elderly individuals will continue to grow from current levels of five percent to levels of approximately ten percent over subsequent decades [2]. Accompanied by this rise in age and lifespan of the world's population is the increased incidence of chronic neurodegenerative disorders that includes Alzheimer's disease (AD) [3,4]. AD can be of familial or sporadic origin. Familial cases of $\mathrm{AD}$ occur as an autosomal dominant form of a mutated amyloid precursor protein (APP) gene as well as mutations in the presenilin 1 or 2 genes. Occurrence of familial cases of $\mathrm{AD}$ is relatively rare, usually presents prior to age 55 [5], and is present in less than 2 percent of all presentations [6]. Familial AD has been reported in approximately two hundred families throughout the world. Variable single-gene mutations on chromosome 1 lead to altered presenilin 2, mutations on chromosome 14 result in altered presenilin 1 , and mutations on chromosome 21 lead to altered APP. For sporadic $\mathrm{AD}$, almost ten percent of the population over the age of 65 suffers from this disorder [7].

\section{Targeting novel therapies for Alzheimer's disease with forkhead transcription factors}

With the advancing age of the global population and the progressive increase observed in life span, it is estimated that the incidence of sporadic AD will significantly increase throughout the world [7-9]. In addition, healthcare resources will be greatly impacted. In the Unites
States (US) alone, greater than five million individuals are diagnosed with sporadic $\mathrm{AD}$ and approximately four million are under treatment at an annual cost of 3.8 billion US dollars. The onset and progression of $\mathrm{AD}$ is multifactorial. Underlying mechanisms that may lead to cognitive impairment involve cellular injury from $\beta$-amyloid $(A \beta)$, tau, excitotoxicity, mitochondrial damage, acetylcholine loss, astrocytic cell injury, oxidative stress, and cellular metabolic dysfunction [1020]. In light of the multiple pathways that may be responsible for the onset of $\mathrm{AD}$, developing therapies are designed to focus on a variety of targets that include DNA methylation, deployment of monoclonal antibodies against $A \beta$, prevention of $A \beta$ and tau aggregation, increased cytokine and growth factor signal transduction, mammalian target of rapamycin (mTOR) modulation, and the application of metal chelators [14,15,17,18,21-27]. However, included in this growing arsenal of potential targets are mammalian forkhead transcription factors of the $\mathrm{O}$ class. FoxOs may represent one of the most exciting and novel strategies for the development of therapies against AD.

The FoxO family of proteins and modulation of FoxO transcription factor activity

More than one hundred forkhead genes and 19 human subgroups that range from FOXA to FOXS are now known to exist since

Correspondence to: Kenneth Maiese, MD, Cellular and Molecular Signaling, USA, E-mail: wntin75@yahoo.com

Key words: Akt, apoptosis, autophagy, cell longevity, forkhead transcription factors, FoxO, growth factors, erythropoietin, mechanistic target of rapamycin (mTOR), mitochondria, oxidative stress, programmed cell death, reactive oxygen species, SIRT1, sirtuins, stem cells, transcription factors, WISP1, Wnt signaling

Received: June 01, 2016; Accepted: June 10, 2016; Published: June 14, 2016 
the discovery of the Drosophila melanogaster gene forkhead [28]. Mammalian FOXO proteins that are of the O class of the forkhead box class transcription factors have the members FOXO1, FOXO3, FOXO4, and FOXO6 [29]. In relation to the nomenclature for forkhead box class transcription factors, an Arabic number is used with the designation of "Fox", followed by a subclass or subgroup letter, and then the member number is listed within the subclasses of the Fox proteins [30]. For human Fox proteins, all letters are capitalized. Only the initial letter is listed as uppercase for the mouse and for all other chordates the initial and subclass letters are in uppercase [31-34]. FoxO proteins are transcription factors and bind to deoxyribonucleic acid [DNA] through the FoxO-recognized element in the C-terminal basic region of the forkhead DNA binding domain [35,36]. It is important to note that multiple mechanisms may affect forkhead protein binding to DNA. These mechanisms can involve variations in the $\mathrm{N}$-terminal region of the recognition helix, changes in electrostatic distribution, and blockade of nuclear translocation of FoxO proteins [37-40]. Following forkhead binding to DNA, target gene expression is repressed or activated through fourteen protein-DNA contacts with the primary recognition site located at $\alpha$-helix $\mathrm{H} 3$ [41]. In addition, phosphorylation or acetylation of forkhead proteins can block FoxO activity and alter the binding of the C-terminal basic region to DNA to prevent transcriptional activity [42].

Phosphorylation of forkhead transcription factors can be controlled by the serine-threonine kinase protein kinase B (Akt) [7,4348]. Akt phosphorylates FoxO proteins that result in the binding of FoxOs to cytoplasmic 14-3-3 proteins. This action prevents nuclear translocation of FoxOs and blocks the transcription of target genes that promote apoptosis [49-52]. Other pathways in addition to Akt also can lead to the phosphorylation and inactivation of FoxO proteins. The serum- and glucocorticoid-inducible protein kinase (SgK), a member of a family of kinases termed AGC (protein kinase A/protein kinase $\mathrm{G}$ /protein kinase $\mathrm{C}$ ) kinases that includes Akt, phosphorylates FoxO3a to sequester forkhead proteins in the cytoplasm [53]. Since Akt and SgK phosphorylate FoxO proteins at different sites, it may be possible to exploit this knowledge to allow for increased options for controlling forkhead protein activity. Yet, some protein kinases such as mammalian sterile 20-like kinase-1 (MST1) can phosphorylate FOXO proteins and disrupt the binding to 14-3-3 which then allows FOXO nuclear translocation and subsequent death in neurons [38], further suggesting that the phosphorylation site of FoxO proteins is crucial in determining the activity of forkhead transcription factors.

Ubiquitylation and acetylation also control post-translational modification and activity of FoxO proteins [54,55]. For example, Akt also leads to the ubiquitination and degradation of FoxO proteins through the $26 \mathrm{~S}$ proteasome [55,56]. Agents that can prevent the ubiquitination and degradation of FoxO proteins may serve as important entities to induce apoptotic cell death in cancers that can be tied to silent mating type information regulation 2 homolog 1 (Saccharomyces cerevisiae) (SIRT1) [57,58]. In a similar vein, SIRT1 activity also can lead to enhanced cell survival such as in the nervous system through modulation of FoxO activity [59-63].

FoxO proteins are acetylated by histone acetyltransferases that include p300, the CREB-binding protein (CBP), and the CBPassociated factor. Once acetylated, FoxO proteins translocate to the cell nucleus but have diminished activity since acetylation of lysine residues on FoxO proteins has been shown to limit the ability of FoxO proteins to bind to DNA [64]. Furthermore, acetylation can increase phosphorylation of FoxO proteins through Akt [64]. In contrast, increased activity of FoxO proteins such as during deacetylation can lead to cytochrome $\mathrm{c}$ release and caspase-induced apoptotic death [37,48,63,65-68].

\section{FoxO proteins drive cellular survival through apoptosis and autophagy}

FoxO proteins may play multiple roles in the nervous system $[36,69]$. For example, forkhead transcription factors, such as FoxO3, may control cerebral endothelial vascular cell survival [70,71], oxidative stress injury in mouse cerebellar granule neurons [72], neonatal hypoxic-ischemic encephalopathy [73], erythroid cell growth [74], and hippocampal neuronal injury $[51,75]$. FoxO transcription factors also appear to be involved in memory formation and consolidation [76] especially since these transcription factors are present in several regions of the brain, such as the hippocampus, the amygdala, and the nucleus accumbens $[77,78]$.

FoxO proteins oversee cell survival in the nervous system through the programmed cell death pathways of apoptosis and autophagy $[79,80]$. Under a number of conditions, FoxO transcription factors lead to apoptotic cell death that can involve oxidative stress [81]. In regards to FoxO1 or FoxO3a, inhibition or gene knockdown of these transcription factors leads to stroke reduction by estradiol [52], protects against microglial cell demise during oxidative stress [82] and $\beta$-amyloid $(A \beta)$ exposure [83], promotes the protective effects of metabotropic glutamate receptors [65], increases neuronal cell survival through nicotinamide adenine dinucleotide $\left(\mathrm{NAD}^{+}\right)$precursors [66], and provides trophic factor protection with erythropoietin (EPO) $[37,50,70,74]$ and neurotrophins [84-86]. Other pathways also rely upon the down-regulation of FoxO to foster cellular survival and block apoptosis. Wnt signaling pathways [87] with Wnt1 in microglial cells of the central nervous system prevents apoptosis through the posttranslational phosphorylation and sequestration of FoxO3a in the cytoplasm to prevent the loss of mitochondrial membrane permeability, cytochrome $\mathrm{c}$ release, Bad phosphorylation, and activation of caspases [68]. Wnt1 inducible signaling pathway protein 1 (WISP1), a target of Wnt signaling $[88,89]$, also protects neurons through the posttranslational phosphorylation of FoxO3a, sequestration of FoxO3a in the cytoplasm with protein 14-3-3, and limiting the deacytelation of FoxO3a [51]. Neuroprotective trophic factors and cytokines, such as EPO [30,37,70], also use Wnt signaling to offer cellular protection through the inhibition of FoxO proteins. However, other studies show that in some cellular populations, such as mouse hematopoietic stem cells, the conditional deletion of FoxO1, FoxO3a, and FoxO4 can lead to an increase in reactive oxygen species [ROS] [90], suggesting that FoxO proteins in some environments can be beneficial in the regulation of oxidative stress [91,92].

During the induction of autophagy $[93,94]$, FoxO proteins may enhance cellular survival. In experimental models of full-length mutant Huntingtin (mHtt) transgenic mice, ectopic expression of FoxO1 enhances autophagy and toxic $\mathrm{mHtt}$ protein clearance in neuronal cell cultures [95]. Activation of FoxO proteins and autophagy also may prevent apoptotic cell injury during oxidative stress such as in chondrocytes [96]. Loss of FoxO activity with reduction of autophagy during aging may contribute to neuronal dysfunction and the induction of $\mathrm{A} \beta$ production [97]. However, during development, repression of FoxO activity and blockade of autophagy may be necessary for improved cell survival. For example, loss of Foxo that prevents autophagy induction and the combined inhibition of reaper pro-apoptotic genes leads to long-term survival of neuroblasts and 
neurogenesis in centers responsible for learning and memory in Drosophila [98].

\section{FoxO proteins oversee stem cell survival development and differentiated cell survival}

FoxO proteins can influence neuronal precursor development and the maintenance of neurons $[3,99]$. Loss of Foxa1 and Foxa2 in mice results in reduced striatal dopamine metabolites, loss of dopaminergic cells, and progressive locomotor deficits [100]. In signaling pathways that involve WISP1, FoxO may be detrimental to stem cell development. WISP1 expression is up-regulated during stem cell migration [101] and affects induced pluripotent stem cell reprogramming [102,103]. Since WISP1 requires $\beta$-catenin for the differentiation of marrow derived mesenchymal stem cells [104], FoxO may interfere with this process and bind to $\beta$-catenin that ultimately blocks stem cell development $[88,105]$. In addition, the growth factor EPO [106] requires control of FoxO3a activity to promote eythroid progenitor cell development [74,107-109]. Glial cell line-derived neurotrophic factor also inhibits FoxO1 and FoxO3a activity to promote rat enteric nervous system precursor development [110].

In differentiated cells of the nervous system, FoxO activation may impair cellular survival [111]. Toxin exposure in cortical neurons that activates FoxO3a and p27 (kip1) transcription leads to apoptosis [112]. In addition, FoxO3a association with cell cycle induction proteins has been suggested to result in neuronal apoptotic cell death [72]. Manganese toxicity, a potential factor in neurodegenerative disorders such as Parkinson's disease [113], has been tied to astrocyte cell death through increased expression and activation of FoxO proteins [114]. Protection of cells in the nervous system occurs with the inhibition of FoxO activity and the blockade of FoxO translocation to the nucleus [115]. Furthermore, FoxO3 inactivation is necessary during antioxidant administration for the protection of cortical neurons and hippocampal neuronal cell lines in the presence of excitotoxicity [116] and in experimental models of $\mathrm{AD}$ with $\mathrm{A} \beta$ toxicity [75]. Protection of primary hippocampal neurons by group I metabotropic receptors during oxidative stress also requires the phosphorylation and inactivation of FoxO3a and the blockade of caspase activation by FoxO3a [65]. EPO has been shown to offer neuronal and vascular cell protection $[117,118]$ through pathways that inactivate FoxO proteins, such as FoxO3a [50,74]. Knockdown of FoxO3a and prevention of nuclear shuttling leads to the increased survival in microglial cells and neurons of the nervous system [51,68]. Cortical neurons [119] and vascular cells $[37,70,120,121]$ also are protected through inhibitory phosphorylation of FoxO3a and the nuclear export of this protein during periods of elevated glucose.

On the flip-side, FoxO protein activity is sometimes necessary for neuronal protection. FoxO proteins such as FoxO3 may be important for the control of autophagic flux in Parkinson's disease [122]. A small degree of FoxO3 activity blocks nigral neuron cell death by reducing a-synuclein levels and fostering the accumulation of autophagic vacuoles containing lipofuscin [122]. FoxO3a may be necessary for cochlear auditory activity and the maintenance of synaptic function [123]. Increased FoxO protein expression prevents neurodegenerative disease and adverse behavioral deficits during selenium exposure that may linked to the development of amyotrophic lateral sclerosis [124]. Activation of FoxO proteins also may be protective during aging such that loss of FoxO3a activity results in decreased manganese-superoxide dismutase and enhanced cell injury with aging [125]. Loss of FoxO results in decreased survival and locomotive activity in Drosophila models of A $\beta$ toxicity [126]. Yet, it should be noted that the level of FoxO activity as well as associated pathways that involve SIRT1 may be critical for survival and function of cells in the nervous system. If one considers other systems of the body, it has been suggested that a controlled up-regulation of FoxO3a and SIRT1 expression in cardiac tissue may be beneficial during exercise [127]. Levels of SIRT1 that are less than 7.5-fold are associated with catalase expression that is also controlled by FoxOla to possibly reduce cell injury during oxidative stress. In contrast, elevated levels of SIRT1 at 12.5 -fold can result in cardiomyocyte apoptosis and decreased cardiac function [128].

\section{Determining the role of FoxO proteins in alzheimer's disease and cognitive impairment}

FoxO proteins are deacetylated by histone deacetylases, such as SIRT1 [56,129-131], that can be beneficial under certain conditions. SIRT1-mediated deacetylation of FoxO1 leads to starvation-induced increases in autophagic flux that can maintain cardiac left ventricular function during periods of starvation [132]. SIRT1 can promote cortical bone formation with osteoblast progenitors by deacetylation of FoxOs and preventing FoxO protein from inhibiting Wnt signaling through the binding of FoxO to $\beta$-catenin [133]. In addition, it is important to note that SIRT1 also can modulate activity of FoxOs under other conditions to increase cell survival in the brain [15] through the inhibition of FoxOs [51,70,121,134].

Sirtuins and FoxO proteins also may function synergistically to promote neuronal cell survival $[3,61]$. In experimental cell culture models, FoxO proteins in conjunction with SIRT1 pathways may offer protection against $A \beta$ toxicity [135]. Forkhead transcription factors, such as FoxO3a, may be dependent upon SIRT1 to reduce oxidative stress and cell injury during exposure to $A \beta$ [136]. SIRT1-mediated deacetylation of FoxO1 can protect cells from ischemic injury [137]. In microglia, overexpression of SIRT3 has been linked to antioxidant expression through enhanced activity of FoxO3a [138]. FoxO proteins also can regulate SIRT1 transcription and increase SIRT1 expression [139]. Loss of FoxO and SIRT1 activity with a reduction in autophagy activity, at least in models of Drosophila, may lead to increased neuronal induction of $A \beta$ [97].

In other studies, FoxO proteins may assist with cell injury during Alzheimer's disease. Nuclear translocation of FoxO3 is associated with DNA damage [140] and $A \beta$ toxicity that leads to dephosphorylation and mitochondrial translocation of FoxO3a with subsequent mitochondrial dysfunction [141], suggesting that down-regulation of FoxO3a could block $A \beta$ toxicity. In addition, astrocyte cell death during $A \beta$ exposure has been associated with activation of FoxO3a and the pro-apoptotic target Bim and caspase 3 [142]. Histone deacetylase 2 [HDAC2] has been shown to form a physical complex with FoxO3a that plays a role with oxidative stress-induced cerebellar granule neuron apoptosis [72]. Inhibition of forkhead transcription factor activity protects against oxidative stress and A toxicity $[83,126]$ that may point to new therapeutic targets for Alzheimer's disease [7]. Furthermore, blockade of a calcineurin/FoxO3 interaction in astrocytes during $\mathrm{A} \beta$ exposure may decrease pro-inflammatory cytokines and protect neurons [143].

\section{Future perspectives}

Mammalian forkhead transcription factors of the FoxO family offer exciting prospects for the treatment of cognitive neurodegenerative disorders and $\mathrm{AD}$. FoxOs are present in multiple regions of the brain that can influence cognition and memory to include the hippocampus, the amygdala, and the nucleus accumbens. In addition, FoxOs may be 
necessary for memory formation and consolidation. In regards to cell survival, FoxOs control both apoptotic and autophagic pathways. For the most part, limiting FoxO activity is necessary to block apoptotic cell death. However, the degree that specific FoxO protein activity is reduced appears to be critical, since under some circumstances FoxO activity is necessary to protect against oxidative stress. In addition, fostering the induction of autophagy by FoxOs is required for conditions that involve neurogenesis and memory development. FoxOs are intricately involved with multiple pathways that include growth factors, such as EPO and neurotrophins, Wnt signaling, WISP1, and SIRT1. With each of these pathways, post-translational modification of FoxO proteins and subsequent FoxO cellular activity can influence how FoxOs drive cellular survival and potentially affect cognitive function. Future work that continues to tease apart the complex relationship that FoxOs hold for cognitive function should bear significant fruits for the development of new strategies to treat neurodegenerative disorders such as $\mathrm{AD}$.

\section{Acknowledgments}

This research was supported by the following grants to Kenneth Maiese: American Diabetes Association, American Heart Association, NIH NIEHS, NIH NIA, NIH NINDS, and NIH ARRA.

\section{References}

1. Maiese K (2016) Novel nervous and multi-system regenerative therapeutic strategies for diabetes mellitus with mTOR. Neural Regen Res 11: 372-385. [Crossref]

2. Maiese K (2016) Molecules to Medicine with mTOR: Translating Critical Pathways into Novel Therapeutic Strategies. Elsevier and Academic Press.

3. Maiese K (2015) SIRT1 and stem cells: In the forefront with cardiovascular disease, neurodegeneration and cancer. World J Stem Cells 7: 235-242. [Crossref]

4. Martin A, Tegla CA, Cudrici CD, Kruszewski AM, Azimzadeh P, et al. (2015) Role of SIRT1 in autoimmune demyelination and neurodegeneration. Immunol Res 61: 187197. [Crossref]

5. Agis-Torres A, Solhuber M, Fernandez M, Sanchez-Montero JM (2014) Multi-TargetDirected Ligands and other Therapeutic Strategies in the Search of a Real Solution for Alzheimer's Disease. Curr Neuropharmacol. 12: 2-36. [Crossref]

6. Maiese K, Chong ZZ, Hou J, Shang YC (2009) New strategies for Alzheimer's disease and cognitive impairment. Oxid Med Cell Longev 2: 279-289. [Crossref]

7. Maiese K (2014) Taking aim at Alzheimer's disease through the mammalian target of rapamycin. Ann Med 46: 587-596. [Crossref]

8. Maiese K (2014) Driving neural regeneration through the mammalian target of rapamycin. Neural Regen Res 9: 1413-1417. [Crossref]

9. Schluesener JK, Zhu X, Schluesener HJ, Wang GW, Ao P (2014) Key network approach reveals new insight into Alzheimer's disease. IET Syst Biol 8: 169-175. [Crossref]

10. Bellozi PM, Lima IV, Deria JG, Vieira L, Campos AC, et al. (2016) Neuroprotective effects of the anticancer drug NVP-BEZ23 (dactolisib) on amyloid 1-42 induced neurotoxicity and memory impairment. Sci Rep 6: 25226. [Crossref]

11. Busse S, Steiner J, Glorius S, Dobrowolny H, Greiner-Bohl S, et al. (2015) VGF expression by T lymphocytes in patients with Alzheimer's disease. Oncotarget 6:1484314851. [Crossref]

12. Dong W, Wang R, Ma LN, Xu BL, Zhang JS, et al. (2016) Influence of age-related learning and memory capacity of mice: different effects of a high and low caloric diet. Aging Clin Exp Res 28: 303-311. [Crossref]

13. Frederick C, Ando K, Leroy K, Heraud C, Suain V, et al. (2015) Rapamycin ester analog CCI-779/Temsirolimus alleviates tau pathology and improves motor deficit in mutant tau transgenic mice. J Alzheimers Dis 44: 1145-1156. [Crossref]

14. Latacz A, Russell JA, Oclon E, Zubel-lojek J, Pierzchala-Koziec K (2015) mTOR Pathway - Novel Modulator of Astrocyte Activity. Folia Biol (Krakow) 63: 95-105. [Crossref]

15. Maiese K (2015) Targeting molecules to medicine with mTOR, autophagy, and neurodegenerative disorders. Br J Clin Pharmacol. [Crossref]

16. Maiese K, Chong ZZ, Shang YC, Wang S (2013) mTOR: on target for novel therapeutic strategies in the nervous system. Trends Mol Med 19: 51-60. [Crossref]

17. Shi X, Yan C, Liu B, Yang C, Nie X, et al. (2015) miR-381 Regulates Neural Stem Cell Proliferation and Differentiation via Regulating Hes1 Expression. PLoS One 10: e0138973. [Crossref]

18. Snyder C, Stefano GB (2015) Mitochondria and chloroplasts shared in animal and plant tissues: significance of communication. Med Sci Monit 21: 1507-1511. [Crossref]

19. Thorne N, Malik N, Shah S, Zhao J, Class B, et al. (2016) High-Throughput Phenotypic Screening of Human Astrocytes to Identify Compounds That Protect Against Oxidative Stress. Stem Cells Transl Med 5: 613-627. [Crossref]

20. Wang H, Wang H, Cheng H, Che Z (2016) Ameliorating effect of luteolin on memory impairment in an Alzheimer's disease model. Mol Med Rep 13: 4215-4220. [Crossref]

21. Esmaeili Tazangi P, Moosavi SM, Shabani M, Haghani M (2015) Erythropoietin improves synaptic plasticity and memory deficits by decrease of the neurotransmitter release probability in the rat model of Alzheimer's disease. Pharmacol Biochem Behav 130: 15-21. [Crossref]

22. Lauzon MA, Daviau A, Marcos B, Faucheux N (2015) Growth factor treatment to overcome Alzheimer's dysfunctional signaling. Cell Signal 27: 1025-1038. [Crossref]

23. Maiese K (2015) Anovel prescription for Alzheimer's disease: targeting hypercoagulable states. Curr Neurovasc Res 12: 1-3. [Crossref]

24. Ramanan VK, Nho K, Shen L, Risacher SL, Kim S, et al. (2015) FASTKD2 is associated with memory and hippocampal structure in older adults. Mol Psychiatry 20: 1197-1204. [Crossref]

25. Xiao FH, He YH, Li QG, Wu H, Luo LH, et al. (2015) A genome-wide scan reveals important roles of DNA methylation in human longevity by regulating age-related disease genes. PLoS One 10: e0120388. [Crossref]

26. Yao K, Wu J, Zhang J, Bo J, Hong Z, et al. (2016) Protective Effect of DHT on Apoptosis Induced by U18666A via PI3K/Akt Signaling Pathway in C6 Glial Cell Lines. Cell Mol Neurobiol 36: 801-809. [Crossref]

27. Zhao H, Wang ZC, Wang KF, Chen XY (2015) Abeta peptide secretion is reduced by Radix Polygalae-induced autophagy via activation of the AMPK/mTOR pathway. Mol Med Rep 12: 2771-2776. [Crossref]

28. Weigel D, Jurgens G, Kuttner F, Seifert E, Jackle H (1989) The homeotic gene fork head encodes a nuclear protein and is expressed in the terminal regions of the Drosophila embryo. Cell 57: 645-658.[Crossref]

29. Maiese K (2010) Forkhead Transcription Factors: Vital Elements in Biology and Medicine. Advances in Experimental Medicine and Biology, Springer Science and Business Media.

30. Maiese K, Hou J, Chong ZZ, Shang YC (2009) A fork in the path: Developing therapeutic inroads with FoxO proteins. Oxid Med Cell Longev 2: 119-129. [Crossref]

31. Cheng Z, White MF (2011) Targeting Forkhead box O1 from the concept to metabolic diseases: lessons from mouse models. Antioxid Redox Signal 14: 649-661. [Crossref]

32. Kaestner KH, Knochel W, Martinez DE (2000) Unified nomenclature for the winged helix/forkhead transcription factors. Genes Dev 14: 142-146. [Crossref]

33. Maiese K, Chong ZZ, Shang YC, Hou J (2009) FoxO proteins: cunning concepts and considerations for the cardiovascular system. Clin Sci (Lond) 116: 191-203. [Crossref]

34. Shao S, Yang Y, Yuan G, Zhang M, Yu X (2013) Signaling molecules involved in lipidinduced pancreatic beta-cell dysfunction. DNA Cell Biol 32: 41-49. [Crossref]

35. Biggs WH 3rd, Cavenee WK, Arden KC (2001) Identification and characterization of members of the FKHR (FOX O) subclass of winged-helix transcription factors in the mouse. Mamm Genome 12: 416-425. [Crossref]

36. Huang H, Tindall DJ (2007) Dynamic FoxO transcription factors. J Cell Sci 120: 24792487. [Crossref]

37. Chong ZZ, Hou J, Shang YC, Wang S, Maiese K (2011) EPO relies upon novel signaling of Wnt1 that requires Akt, FoxO3a, GSK-3beta, and beta- catenin to foster vascular integrity during experimental diabetes. Curr Neurovasc Res 8: 103-120. [Crossref]

38. Lehtinen MK, Yuan Z, Boag PR, Yang Y, Villen J, et al. (2006) A conserved MSTFOXO signaling pathway mediates oxidative-stress responses and extends life span. Cell 125: 987-1001. [Crossref]

39. Scodelaro Bilbao P, Boland R (2013) Extracellular ATP regulates FoxO family of transcription factors and cell cycle progression through PI3K/Akt in MCF-7 cells Biochim Biophys Acta 1830: 4456-4469. [Crossref]

40. Van Der Heide LP, Hoekman MF, Smidt MP (2004) The ins and outs of FoxO shuttling: 
mechanisms of FoxO translocation and transcriptional regulation. Biochem J 380: 297309. [Crossref]

41. Clark KL, Halay ED, Lai E, Burley SK (1993) Co-crystal structure of the HNF-3/fork head DNA-recognition motif resembles histone H5. Nature 364: 412-420. [Crossref]

42. Tsai KL, Sun YJ, Huang CY, Yang JY, Hung MC, et al. (2007) Crystal structure of the human FOXO3a-DBD/DNA complex suggests the effects of post-translational modification. Nucleic Acids Res 35: 6984-6994. [Crossref]

43. Chong ZZ, Li F, Maiese K (2005) Activating Akt and the brain's resources to drive cellular survival and prevent inflammatory injury. Histol Histopathol 20: 299-315. [Crossref]

44. Huang CY, Chan CY, Chou IT, Lien CH, Hung HC, et al. (2013) Quercetin induces growth arrest through activation of FOXO1 transcription factor in EGFRoverexpressing oral cancer cells. J Nutr Biochem 24: 1596-1603. [Crossref]

45. Maiese K, Chong ZZ, Shang YC (2007) Mechanistic insights into diabetes mellitus and oxidative stress. Curr Med Chem 14: 1729-1738. [Crossref]

46. Park J, Ko YS, Yoon J, Kim MA, Park JW, et al. (2013) The forkhead transcription factor FOXO1 mediates cisplatin resistance in gastric cancer cells by activating phosphoinositide 3-kinase/Akt pathway. Gastric Cancer 17: 423-430. [Crossref]

47. Puthanveetil P, Wan A, Rodrigues B (2013) FoxO1 is crucial for sustaining cardiomyocyte metabolism and cell survival. Cardiovasc Res 97: 393-403. [Crossref]

48. Qi XF, Li YJ, Chen ZY, Kim SK, Lee KJ, et al. (2013) Involvement of the FoxO3a pathway in the ischemia/reperfusion injury of cardiac microvascular endothelial cells. Exp Mol Pathol 95: 242-247. [Crossref]

49. Arimoto-Ishida E, Ohmichi M, Mabuchi S, Takahashi T, Ohshima C, et al. (2004) Inhibition of phosphorylation of a forkhead transcription factor sensitizes human ovarian cancer cells to cisplatin. Endocrinology 145: 2014-2022. [Crossref]

50. Chong ZZ, Maiese K (2007) Erythropoietin involves the phosphatidylinositol 3-kinase pathway, 14-3-3 protein and FOXO3a nuclear trafficking to preserve endothelial cell integrity. Br J Pharmacol 150: 839-850. [Crossref]

51. Wang S, Chong ZZ, Shang YC, Maiese K (2013) WISP1 neuroprotection requires FoxO3a post-translational modulation with autoregulatory control of SIRT1. Curr Neurovasc Res 10: 54-69. [Crossref]

52. Won CK, Ji HH, Koh PO (2006) Estradiol prevents the focal cerebral ischemic injuryinduced decrease of forkhead transcription factors phosphorylation. Neurosci Lett 398 : 39-43. [Crossref]

53. Leong ML, Maiyar AC, Kim B, O'Keeffe BA, Firestone GL (2003) Expression of the serum- and glucocorticoid-inducible protein kinase, Sgk, is a cell survival response to multiple types of environmental stress stimuli in mammary epithelial cells. J Biol Chem 278: 5871-5882. [Crossref]

54. Matsuzaki H, Daitoku H, Hatta M, Tanaka K, Fukamizu A (2003) Insulin-induced phosphorylation of FKHR (Foxo1) targets to proteasomal degradation. Proc Natl Acad Sci U S A 100: 11285-11290. [Crossref]

55. Plas DR, Thompson CB (2003) Akt activation promotes degradation of tuberin and FOXO3a via the proteasome. J Biol Chem 278: 12361-12366. [Crossref]

56. Jagani Z, Singh A, Khosravi-Far R (2008) FoxO tumor suppressors and BCR-ABLinduced leukemia: a matter of evasion of apoptosis. Biochim Biophys Acta 1785: 63-84. [Crossref]

57. Carbajo-Pescador S, Mauriz JL, Garcia-Palomo A, Gonzalez-Gallego J (2014) FoxO proteins: regulation and molecular targets in liver cancer. Curr Med Chem 21: 12311246. [Crossref]

58. Wang F, Chan CH, Chen K, Guan X, Lin HK, et al. (2012) Deacetylation of FOXO3 by SIRT1 or SIRT2 leads to Skp2-mediated FOXO3 ubiquitination and degradation. Oncogene 31: 1546-1557. [Crossref]

59. Chong ZZ, Shang YC, Wang S, Maiese K (2012) SIRT1: new avenues of discovery for disorders of oxidative stress. Expert Opin Ther Targets 16: 167-178. [Crossref]

60. Chong ZZ, Wang S, Shang YC, Maiese K (2012) Targeting cardiovascular disease with novel SIRT1 pathways. Future Cardiol 8: 89-100. [Crossref]

61. Maiese K, Chong ZZ, Shang YC, Wang S (2011) Translating cell survival and cell longevity into treatment strategies with SIRT1. Rom J Morphol Embryol 52: 11731185. [Crossref]

62. Paraiso AF, Mendes KL, Santos SH (2013) Brain activation of SIRT1: role in neuropathology. Mol Neurobiol 48: 681-689. [Crossref]
63. Wang W, Yan C, Zhang J, Lin R, Lin Q, et al. (2013) SIRT1 inhibits TNF-alpha-induced apoptosis of vascular adventitial fibroblasts partly through the deacetylation of FoxO1. Apoptosis 18: 689-701. [Crossref]

64. Matsuzaki H, Daitoku H, Hatta M, Aoyama H, Yoshimochi K, et al. (2005) Acetylation of Foxol alters its DNA-binding ability and sensitivity to phosphorylation. Proc Natl Acad Sci U S A 102: 11278-11283. [Crossref]

65. Chong ZZ, Li F, Maiese K (2006) Group I metabotropic receptor neuroprotection requires Akt and its substrates that govern FOXO3a, Bim, and beta-catenin during oxidative stress. Curr Neurovasc Res 3: 107-117. [Crossref]

66. Chong ZZ, Lin SH, Maiese K (2004) The NAD+ precursor nicotinamide governs neuronal survival during oxidative stress through protein kinase B coupled to FOXO3a and mitochondrial membrane potential. J Cereb Blood Flow Metab 24: 728-743. [Crossref]

67. Obexer P, Geiger K, Ambros PF, Meister B, Ausserlechner MJ (2007) FKHRL1mediated expression of Noxa and Bim induces apoptosis via the mitochondria in neuroblastoma cells. Cell Death Differ 14: 534-547. [Crossref]

68. Shang YC, Chong ZZ, Hou J, Maiese K (2010) Wnt, FoxO3a, and NF-kappaB oversee microglial integrity and activation during oxidant stress. Cell Signal 22: 1317-1329. [Crossref]

69. Maiese K, Chong ZZ, Hou J, Shang YC (2009) The "O" class: crafting clinical care with FoxO transcription factors. Adv Exp Med Biol 665: 242-260. [Crossref]

70. Hou J, Wang S, Shang YC, Chong ZZ, Maiese K (2011) Erythropoietin employs cell longevity pathways of SIRT1 to foster endothelial vascular integrity during oxidant stress. Curr Neurovasc Res 8: 220-235. [Crossref]

71. Maiese K, Li F, Chong ZZ (2005) New avenues of exploration for erythropoietin. JAMA 293: 90-95. [Crossref]

72. Peng S, Zhao S, Yan F, Cheng J, Huang L, et al. (2015) HDAC2 selectively regulates FOXO3a-mediated gene transcription during oxidative stress-induced neuronal cell death. J Neurosci 35: 1250-1259. [Crossref]

73. Rong Z, Pan R, Xu Y, Zhang C, Cao Y, et al. (2013) Hesperidin pretreatment protects hypoxia-ischemic brain injury in neonatal rat. Neuroscience 255: 292-299. [Crossref]

74. Chamorro ME, Wenker SD, Vota DM, Vittori DC, Nesse AB (2013) Signaling pathways of cell proliferation are involved in the differential effect of erythropoietin and its carbamylated derivative. Biochim Biophys Acta 1833: 1960-1968. [Crossref]

75. Zeldich E, Chen CD, Colvin TA, Bove-Fenderson EA, Liang J, et al. (2014) The neuroprotective effect of Klotho is mediated via regulation of members of the redox system. J Biol Chem 289: 24700-24715. [Crossref]

76. Salih DA, Rashid AJ, Colas D, de la Torre-Ubieta L, Zhu RP, et al. (2012) FoxO6 regulates memory consolidation and synaptic function. Genes Dev 26: 2780-2801. [Crossref]

77. Hoekman MF, Jacobs FM, Smidt MP, Burbach JP (2006) Spatial and temporal expression of FoxO transcription factors in the developing and adult murine brain Gene Expr Patterns 6: 134-140. [Crossref]

78. van der Heide LP, Jacobs FM, Burbach JP, Hoekman MF, Smidt MP (2005) FoxO6 transcriptional activity is regulated by Thr26 and Ser18, independent of nucleocytoplasmic shuttling. Biochem J 391: 623-629. [Crossref]

79. Maiese K (2015) FoxO proteins in the nervous system. Anal Cell Pathol (Amst) 2015 569392. [Crossref]

80. Sun F, Han DF, Cao BQ, Wang B, Dong N, et al. (2015) Caffeine-induced nuclear translocation of FoxO1 triggers Bim-mediated apoptosis in human glioblastoma cells. Tumour Biol 37: 3417-3423. [Crossref]

81. Nakamura T, Sakamoto K (2008) Forkhead transcription factor FOXO subfamily is essential for reactive oxygen species-induced apoptosis. Mol Cell Endocrinol 281: 47 55. [Crossref]

82. Shang YC, Chong ZZ, Hou J, Maiese K (2009) FoxO3a governs early microglial proliferation and employs mitochondrial depolarization with caspase, 8 , and 9 cleavage during oxidant induced apoptosis. Curr Neurovasc Res 6: 223-238. [Crossref]

83. Shang YC, Chong ZZ, Hou J, Maiese K (2009) The forkhead transcription factor FoxO3a controls microglial inflammatory activation and eventual apoptotic injury through caspase 3. Curr Neurovasc Res 6: 20-31. [Crossref]

84. Anitha M, Gondha C, Sutliff R, Parsadanian A, Mwangi S, et al. (2006) GDNF rescues hyperglycemia-induced diabetic enteric neuropathy through activation of the PI3K/Akt pathway. J Clin Invest 116: 344-356. [Crossref] 
85. Zheng WH, Kar S, Quirion R (2002) FKHRL1 and its homologs are new targets of nerve growth factor Trk receptor signaling. J Neurochem 80: 1049-1061. [Crossref]

86. Zhu W, Bijur GN, Styles NA, Li X (2004) Regulation of FOXO3a by brain-derived neurotrophic factor in differentiated human SH-SY5Y neuroblastoma cells. Brain Res Mol Brain Res 126: 45-56. [Crossref]

87. Maiese K, Li F, Chong ZZ, Shang YC (2008) The Wnt signaling pathway: aging gracefully as a protectionist? Pharmacol Ther 118: 58-81. [Crossref]

88. Maiese K (2014) WISP1: Clinical insights for a proliferative and restorative member of the CCN family. Curr Neurovasc Res 11: 378-389. [Crossref]

89. Maiese K (2016) Picking a bone with WISP (CCN4): new strategies against degenerative joint disease. J Transl Sci 1: 83-85. [Crossref]

90. Tothova Z, Kollipara R, Huntly BJ, Lee BH, Castrillon DH, et al. (2007) FoxOs are critical mediators of hematopoietic stem cell resistance to physiologic oxidative stress. Cell 128: 325-339. [Crossref]

91. Maiese K (2016) The bright side of reactive oxygen species: lifespan extension without cellular demise. J Transl Sci 2: 185-187. [Crossref]

92. Wang X, Hai C (2016) Novel insights into redox system and the mechanism of redox regulation. Mol Biol Rep . [Crossref]

93. Klionsky DJ, Abdelmohsen K, Abe A, Abedin MJ, Abeliovich H, et al. (2016) Guidelines for the use and interpretation of assays for monitoring autophagy (3rd edition). Autophagy 12: 1-222. [Crossref]

94. Maiese K, Chong ZZ, Shang YC, Wang S (2012) Targeting disease through novel pathways of apoptosis and autophagy. Expert Opin Ther Targets 16: 1203-1214. [Crossref]

95. Vidal RL, Figueroa A, Court FA, Thielen P, Molina C, et al. (2012) Targeting the UPR transcription factor XBP1 protects against Huntington's disease through the regulation of FoxO1 and autophagy. Hum Mol Genet 21: 2245-2262. [Crossref]

96. Akasaki Y, Alvarez-Garcia O, Saito M, Carames B, Iwamoto Y, et al. (2014) FOXO transcription factors support oxidative stress resistance in human chondrocytes. Arthritis Rheumatol 66: 3349-3358. [Crossref]

97. Omata Y, Lim YM, Akao Y, Tsuda L (2014) Age-induced reduction of autophagy-related gene expression is associated with onset of Alzheimer's disease. Am J Neurodegener Dis 3: 134-142. [Crossref]

98. Siegrist SE, Haque NS, Chen CH, Hay BA, Hariharan IK (2010) Inactivation of both Foxo and reaper promotes long-term adult neurogenesis in Drosophila. Curr Biol 20: 643-648. [Crossref]

99. Genin EC, Caron N, Vandenbosch R, Nguyen L, Malgrange B (2014) Concise review: forkhead pathway in the control of adult neurogenesis. Stem Cells 32: 1398-1407. [Crossref]

100. Domanskyi A, Alter H, Vogt MA, Gass P, Vinnikov IA (2014) Transcription factors Foxa1 and Foxa2 are required for adult dopamine neurons maintenance. Front Cell Neurosci 8: 275. [Crossref]

101. Lough D, Dai H, Yang M, Reichensperger J, Cox L, et al. (2013) Stimulation of the follicular bulge LGR5+ and LGR6+ stem cells with the gut-derived human alpha defensin 5 results in decreased bacterial presence, enhanced wound healing, and hair growth from tissues devoid of adnexal structures. Plast Reconstr Surg 132: 1159-1171. [Crossref]

102. Jung DW, Kim WH, Williams DR (2014) Reprogram or reboot: small molecule approaches for the production of induced pluripotent stem cells and direct cell reprogramming. ACS Chem Biol 9: 80-95. [Crossref]

103. Yang CS, Lopez CG, Rana TM (2011) Discovery of nonsteroidal anti-inflammatory drug and anticancer drug enhancing reprogramming and induced pluripotent stem cell generation. Stem Cells 29: 1528-1536. [Crossref]

104. Case N, Xie Z, Sen B, Styner M, Zou M, et al. (2010) Mechanical activation of betacatenin regulates phenotype in adult murine marrow-derived mesenchymal stem cells. J Orthop Res 28: 1531-1538. [Crossref]

105. Heo J, Ahn EK, Jeong HG, Kim YH, Leem SH, et al. (2013) Transcriptional characterization of Wnt pathway during sequential hepatic differentiation of human embryonic stem cells and adipose tissue-derived stem cells. Biochem Biophys Res Commun 434: 235-240. [Crossref]

106. Maiese K (2016) Regeneration in the nervous system with erythropoietin. Frontiers in bioscience (Landmark edition) 21: 561-596. [Crossref]

107. Bakker WJ, van Dijk TB, Parren-van Amelsvoort M, Kolbus A, Yamamoto K, et al.
(2007) Differential regulation of Foxo3a target genes in erythropoiesis. Mol Cell Biol 27: 3839-3854. [Crossref]

108. Kaushal N, Hegde S, Lumadue J, Paulson RF, Prabhu KS (2011) The regulation of erythropoiesis by selenium in mice. Antioxid Redox Signal 14: 1403-1412. [Crossref]

109. Maiese K, Chong ZZ, Hou J, Shang YC (2010) Oxidative stress: Biomarkers and novel therapeutic pathways. Exp Gerontol 45: 217-234. [Crossref]

110. Srinivasan S, Anitha M, Mwangi S, Heuckeroth RO (2005) Enteric neuroblasts require the phosphatidylinositol 3-kinase/Akt/Forkhead pathway for GDNF-stimulated survival. Mol Cell Neurosci 29: 107-119. [Crossref]

111. Maiese K (2015) FoxO Transcription Factors and Regenerative Pathways in Diabetes Mellitus. Curr Neurovasc Res 12: 404-413. [Crossref]

112. Xu G, Liu J, Yoshimoto K, Chen G, Iwata T, et al. (2014) 2,3,7,8-tetrachlorodibenzo$\mathrm{p}$-dioxin (TCDD) induces expression of $\mathrm{p} 27(\mathrm{kip}(1))$ and FoxO3a in female rat cerebral cortex and PC12 cells. Toxicol Lett 226: 294-302. [Crossref]

113. Lan AP, Chen J, Zhao Y, Chai Z, Hu Y (2016) mTOR Signaling in Parkinson's Disease Neuromolecular Med. [Crossref]

114. Exil V, Ping L, Yu Y, Chakraborty S, Caito SW, et al. (2014) Activation of MAPK and FoxO by manganese $(\mathrm{Mn})$ in rat neonatal primary astrocyte cultures. PLoS One 9: e94753. [Crossref]

115. Maiese K, Chong ZZ, Shang YC, Hou J (2009) A "FOXO" in sight: targeting Foxo proteins from conception to cancer. Med Res Rev 29: 395-418. [Crossref]

116. Bahia PK, Pugh V, Hoyland K, Hensley V, Rattray M, et al. (2012) Neuroprotective effects of phenolic antioxidant $\mathrm{BBHQ}$ associate with inhibition of FoxO3a nuclear translocation and activity. J Neurochem 123: 182-191. [Crossref]

117. Maiese K (2015) Erythropoietin and diabetes mellitus. World J Diabetes 6: 1259-1273. [Crossref]

118. Maiese K (2016) Charting a course for erythropoietin in traumatic brain injury. $J$ Transl Sci 2: 140-144. [Crossref]

119. Wilk A, Urbanska K, Yang S, Wang JY, Amini S, et al. (2011) Insulin-like growth factor-I-forkhead box $\mathrm{O}$ transcription factor 3 a counteracts high glucose/tumor necrosis factor-alpha-mediated neuronal damage: implications for human immunodeficiency virus encephalitis. J Neurosci Res 89: 183-198. [Crossref]

120. Hou J, Chong ZZ, Shang YC, Maiese K (2010) FOXO3a governs early and late apoptotic endothelial programs during elevated glucose through mitochondrial and caspase signaling. Mol Cell Endocrinol 321: 194-206. [Crossref]

121. Hou J, Chong ZZ, Shang YC, Maiese K (2010) Early apoptotic vascular signaling is determined by Sirt1 through nuclear shuttling, forkhead trafficking, bad, and mitochondrial caspase activation. Curr Neurovasc Res 7: 95-112. [Crossref]

122. Pino E, Amamoto R, Zheng L, Cacquevel M, Sarria JC, et al. (2014) FOXO3 determines the accumulation of alpha-synuclein and controls the fate of dopaminergic neurons in the substantia nigra. Hum Mol Genet 23: 1435-1452. [Crossref]

123. Gilels F, Paquette ST, Zhang J, Rahman I, White PM (2013) Mutation of Foxo3 causes adult onset auditory neuropathy and alters cochlear synapse architecture in mice. $J$ Neurosci 33: 18409-18424. [Crossref]

124. Estevez AO, Morgan KL, Szewczyk NJ, Gems D, Estevez M (2014) The neurodegenerative effects of selenium are inhibited by FOXO and PINK1/PTEN regulation of insulin/insulin-like growth factor signaling in Caenorhabditis elegans. Neurotoxicology 41: 28-43. [Crossref]

125. Li M, Chiu JF, Mossman BT, Fukagawa NK (2006) Down-regulation of manganesesuperoxide dismutase through phosphorylation of FOXO3a by Akt in explanted vascular smooth muscle cells from old rats. J Biol Chem 281: 40429-40439. [Crossref]

126. Hong YK, Lee S, Park SH, Lee JH, Han SY, et al. (2012) Inhibition of JNK/dFOXO pathway and caspases rescues neurological impairments in Drosophila Alzheimer's disease model. Biochem Biophys Res Commun 419: 49-53. [Crossref]

127. Ferrara N, Rinaldi B, Corbi G, Conti V, Stiuso P, et al. (2008) Exercise training promotes SIRT1 activity in aged rats. Rejuvenation Res 11: 139-150. [Crossref]

128. Alcendor RR, Gao S, Zhai P, Zablocki D, Holle E, et al. (2007) Sirt1 regulates aging and resistance to oxidative stress in the heart. Circ Res 100: 1512-1521. [Crossref]

129. Maiese K, Chong ZZ, Shang YC (2007) "Sly as a FOXO": new paths with Forkhead signaling in the brain. Curr Neurovasc Res 4: 295-302. [Crossref]

130. Myatt SS, Lam EW (2007) The emerging roles of forkhead box (Fox) proteins in cancer. Nat Rev Cancer 7: 847-859. [Crossref] 
131. van der Horst A, Burgering BM (2007) Stressing the role of FoxO proteins in lifespan and disease. Nat Rev Mol Cell Biol 8: 440-450. [Crossref]

132. Hariharan N, Maejima Y, Nakae J, Paik J, Depinho RA, et al. (2010) Deacetylation of FoxO by Sirt1 Plays an Essential Role in Mediating Starvation-Induced Autophagy in Cardiac Myocytes. Circ Res 107: 1470-1482. [Crossref]

133. Iyer S, Han L, Bartell SM, Kim HN, Gubrij I, et al. (2014) Sirtuin (Sirt1) promotes cortical bone formation by preventing $\beta$-catenin sequestration by FoxO transcription factors in osteoblast progenitors. J Biol Chem 289: 24069-24078. [Crossref]

134. Nerurkar PV, Johns LM, Buesa LM, Kipyakwai G, Volper E, et al. (2011) Momordica charantia (bitter melon) attenuates high-fat diet-associated oxidative stress and neuroinflammation. J Neuroinflammation 8: 64. [Crossref]

135. Guo P, Wang D, Wang X, Feng H, Tang Y, et al. (2016) Effect and mechanism of fuzhisan and donepezil on the sirtuin 1 pathway and amyloid precursor protein metabolism in PC12 cells. Mol Med Rep 13: 3539-3546. [Crossref]

136. Lin CL, Huang WN, Li HH, Huang CN, Hsieh S, et al. (2015) Hydrogen-rich wate attenuates amyloid $\beta$-induced cytotoxicity through upregulation of Sirt1-FoxO3a by stimulation of AMP-activated protein kinase in SK-N-MC cells. Chem Biol Interact 240: 12-21. [Crossref]

137. Zhang F, Hu Y, Xu X, Zhai X, Wang G, et al. (2015) Icariin protects against intestinal ischemia-reperfusion injury. J Surg Res 194: 127-138. [Crossref]
138. Rangarajan P, Karthikeyan A, Lu J, Ling EA, Dheen ST (2015) Sirtuin 3 regulates Foxo3a-mediated antioxidant pathway in microglia. Neuroscience 311: 398-414. [Crossref]

139. Xiong S, Salazar G, Patrushev N, Alexander RW (2011) FoxO1 mediates an autofeedback loop regulating SIRT1 expression. J Biol Chem 286: 5289-5299. [Crossref]

140. Fluteau A, Ince PG, Minett T, Matthews FE, Brayne C, et al. (2015) The nuclear retention of transcription factor FOXO3a correlates with a DNA damage response and increased glutamine synthetase expression by astrocytes suggesting a neuroprotective role in the ageing brain. Neurosci Lett 609: 11-17. [Crossref]

141. Shi C, Zhu J, Leng S, Long D, Luo X (2016) Mitochondrial FOXO3a is involved in amyloid beta peptide-induced mitochondrial dysfunction. J Bioenerg Biomembr 48 189-196. [Crossref]

142. Saha P, Biswas SC (2015) Amyloid-beta induced astrocytosis and astrocyte death Implication of FoxO3a-Bim-caspase3 death signaling. Mol Cell Neurosci 68: 203211. [Crossref]

143. Fernandez AM, Hervas R, Dominguez-Fraile M, Garrido V, Gomez-Gutierrez P, et al. (2016) Blockade of the Interaction of Calcineurin with FOXO in Astrocytes Protects Against Amyloid- $\beta$-Induced Neuronal Death. J Alzheimers Dis 52: 14711478. [Crossref]

Copyright: (C2016 Maiese K. This is an open-access article distributed under the terms of the Creative Commons Attribution License, which permits unrestricted use, distribution, and reproduction in any medium, provided the original author and source are credited. 